\title{
Manajemen Pembelajaran Bahasa Inggris melalui Contextual Teaching And Learning untuk Meningkatkan Prestasi Belajar Siswa Mts Darul Ulum dan Mts Al Imam
}

\author{
Dewi Istanti' ${ }^{1}$, Achmad Sanusi ${ }^{2}$, Deti Rostini ${ }^{3}$ \\ 1,2,3Sekolah Pascasarjana, Universitas Islam Nusantara Bandung \\ E-mail: dewiistanti3@gmail.com, achmadsanusi32@gmail.com, deti rostini11@gmail.com
}

\begin{tabular}{l} 
Article Info \\
\hline Article History \\
Received: 2022-02-03 \\
Revised: 2022-02-22 \\
Published: 2022-03-01 \\
\\
Keywords: \\
Management; \\
Learning; \\
English; \\
CTL; \\
Learning achievement.
\end{tabular}

\begin{abstract}
The purpose of this study was to describe data, facts and information about learning management in learning English using the Contextual Teaching and Learning (CTL) learning model to improve student achievement at MTs Darul Ulum and MTs Al Imam Cikembar, Sukabumi Regency. This study uses a qualitative approach with descriptive analysis method using interview, observation, and documentation studies. The results of this study indicate that the management planning of English learning through Contextual Teaching and Learning (TCL) has been prepared by the madrasa curriculum development team at the beginning of the learning year and the Madrasah curriculum used is the 2013 curriculum, in its implementation it is carried out according to the concept of the Contextual Teaching and Learning model. Learning (TCL) through preliminary activities, core activities (observing, questioning, exploring, associating, communicating) and closing activities. The assessment is carried out through an assessment during the learning process with Authentic Assessment in four language aspects, namely: listening, speaking, reading and writing skills, increasing learning motivation, more active learning, and facilitating achievement. learning objectives in
\end{abstract} accordance with the predetermined KKM.

Kata kunci: Manajemen; Pembelajaran; Bahasa Inggris; CTL;

Prestasi Belajar.

\begin{tabular}{l}
\hline Artikel Info \\
\hline Sejarah Artikel \\
Diterima: 2022-02-03 \\
Direvisi: 2022-02-22 \\
Dipublikasi: 2022-03-01
\end{tabular}

\section{Abstrak}

Tujuan penelitian ini untuk mendeskripsikan data, fakta dan informasi seputar manajemen pembelajaran pada pembelajaran bahasa Inggris menggunakan model pembelajaran Contextual Teaching and Learning (CTL) untuk meningkatkan prestasi belajar siswa di MTs Darul Ulum dan MTs Al Imam Cikembar Kabupaten Sukabumi. Penelitian ini menggunakan pendekatan kualitatif dengan metode deskriptif analisis dengan menggunakan teknik wawancara, observasi, dan studi dokumentasi. Hasil dari penelitian ini menunjukkan bahwa pada perencanaan manajemen pembelajaran bahasa Inggris melalui Contextual Teaching and Learning (TCL) sudah disusun oleh tim pengembang kurikulum madrasah pada awal tahun pembelajaran dan Kurikulum Madrasah yang digunakan adalah Kurikulum 2013, pada pelaksanaannya dilaksanakan sesuai dengan konsep model Contextual Teaching and Learning (TCL) melalui kegiatan pendahuluan, kegiatan inti (mengamati, mempertanyakan, mengeksplorasi, mengasosiasi, mengkomunikasikan) dan kegiatan penutup. Pada penilaian dilaksanakan melalui penilaian selama proses pembelajaran dengan Authentic Assesment dalam empat aspek berbahasa yaitu: kemampuan mendengarkan (listening), berbicara (speaking), membaca (reading), dan menulis (writing), motivasi belajar meningkat, pembelajaran lebih aktif, dan memudahkan pencapaian tujuan pembelajaran sesuai dengan KKM yang telah ditentukan.

\section{PENDAHULUAN}

Pembelajaran adalah proses interaksi siswa dengan pendidikan dan sumber belajar pada suatu lingkungan belajar. Proses pembelajaran pada awalnya meminta guru untuk mengetahui kemampuan dasar yang dimiliki oleh siswa meliputi kemampuan dasarnya, motivasinya, latar belakang akademisnya, latar belakang sosial ekonominya, dan lain sebagainya. Kesiapan guru untuk mengenal karakteristik peserta didik dalam pembelajaan merupakan modal utama penyampaian bahan belajar dan menjadi indikator suksesnya pelaksanaan pembelajaran, masing-masing komponen dalam proses pembelajaran perlu dikelola secara baik. Tujuannya agar masing-masing komponen tersebut dapat dimanfaatkan secara optima, hal ini akan terwujud, jika guru sebagai desainer pembelajaran memiliki kompetensi manajemen pembelajaran, secara sederhana manajemen pembelajaran dapat diartikan usaha untuk mengelola sumber daya yang digunakan dalam pembelajaran, sehingga tujuan pembelajaran dapat dicapai secara efektif dan efisien, menurut Wragg (1997) dalam Ginting (2008:5) pembelajaran yang efektif adalah pembelajaran yang 
memudahkan siswa untuk mempelajari sesuatu yang bermanfaat seperti fakta, keterampilan, nilai, konsep dan bagaimana hidup serasi dengan sesama, atau suatu hasil belajar yang diinginkan, proses pembelajaran bukan sekedar transfer ilmu dari guru kepada peserta didik, melainkan suatu proses kegiatan, yaitu terjadi interaksi antara guru dengan peserta didik serta antara peserta didik dengan peserta didik. Setiap mata pelajaran memiliki karakteristik dan tujuan pembejaran yang berbeda dan tetntu saja guru yang mengajar lebih memahami manajemen pembelajaran yang efektif dan efisien baik terkait dengan perencanaan, pelaksanaan, penilaian hasil pembelajaran dan pengawasan proses pembelajaran dalam setiap mata pelajaran yang diampu oleh guru. Demikian halnya dengan mata pelajaran bahasa Inggris, dalam setiap pencapaian aspek pembelajaran yang meliputi mendengarkan, berbicara, menulis dan membaca, memilik karkteristik pembelajaran yang berbeda sehingga memerlukan keterampilan guru dalam memilih manajemen pembelajaran yang diharapkan.

Sesuai dengan Tujuan Pendidikan Nasional sebagaimana telah dirumuskan dalam UndangUndang Nomor 20 Tahun 2003 adalah untuk berkembangnya potensi peserta didik agar menjadi manusia yang beriman dan bertakwa kepada Tuhan Yang Maha Esa, berakhlak mulia, sehat, berilmu, cakap, kreatif, mandiri dan menjadi warga negara yang demokratis serta bertanggung jawab. Secara singkatnya undangundang tersebut berharap pendidikan dapat membuat peserta didik menjadi kompeten dalam bidangnya, oleh karena itu pembelajaran bahasa Inggris sangat penting diberikan kepada peserta didik, mengingat di era globalisasi dengan persaingan yang sangat ketat, memerlukan keterampilan berbicara yang bersifat universal. Bahasa Inggris merupakan sebuah alat komunikasi yang dapat mengantarkan seseorang berkomunikasi dengan dunia internasional, kiranya sudah waktunya pembelajaran bahasa Inggris dilaksanakan dengan manajemen pembelajaran yang efektif dan efisien, hal ini juga sejalan dengan kurikulum 2013 yang bertujuan menjawab tantangan arus globalisasi dimana kurikulum 2013 ini berbasis karakter dan kompetensi yang diharapkan mampu memecahkan berbagai persoalan khususnya dalam bidang pendidikan, terutama dalam pendidikan pembelajaran bahasa Inggris. Namun kenyataan di lapangan saat ini dalam pembelajaran bahasa Inggris sangat tidak mudah, mengingat kemampuan dasar yang dimiliki peserta didik dari tingkat Sekolah Dasar (SD) dan Sekolah Menengah (SMP) belum mencapai hasil yang optimal, hal ini terjadi adanya beberapa masalah yang menyebabkan kemampuan berbahasa Inggris peserta didik masih rendah yaitu, (1) guru belum sepenuhnya mengimplementasikan pembelajaran bahasa Inggris sesuai dengan rencana pelaksanaan pembelajaran itu sendiri, (2) pembelajaran bahasa Inggris masih bersifat teacher centered, dimana dalam pembelajaran guru masih mendominasi dengan metode ceramah, (3) dalam kegitan belajar mengajar siswa terpaku untuk mengerjakan buku tugas, mendengarkan ceramah dan mengerjakan secara individu, (4) kurangnya pemilihan dan penggunaan sumber pembelajaran, (5) kurangnya fasilitas sarana pembelajaran bahasa Inggris dan tidak adanya laboratorium bahasa inggris, adapun yang menjadi akar permasalahan dari beberapa permasalahan di atas menunjukkan faktor guru mata pelajaran bahasa Inggris belum mengiplementasikan pembelajaran secara aktif dan kreatif, menurut Sari (2021) guru harus mampu menggunakan media yang bervariasi agar pembelajaran lebih menarik sehingga membuat siswa lebih aktif.

\section{METODE PENELITIAN}

Penelitian ini menggunakan metode deskriptif melalui pendekatan kualitatif, dengan pengumpulan data menggunakan observasi, wawancara, studi dokumentasi, metode penelitian ini dilaksanakan sesuai pendapat Sugiyono (2014:9) bahwa "Metode penelitian yang digunakan untuk meneliti pada kondisi objek alamiah, (sebagai lawannya adalah eksperimen) dimana peneliti adalah sebagai instrumen kunci, teknik pengumpulan data dilakukan secara trianggulasi (gabungan), analisis dan bersifat induktif, dan hasil penelitian kualitatif lebih menekankan makna dari pada generalisasi. "Penelitian ini bertujuan untuk mengkaji, menganalisis dan mendeskripsikan data tentang manajemen pembelajaran bahasa Inggris menggunakan model pembelajaran Contextual Teaching and Learning (CTL) dalam meningkatkan prestasi belajar siswa di MTs Al MTs Darul Ulum dan MTs Al Imam Cikembar Kabupaten Sukabumi ditinjau dari fungsi perencanaan, pelaksanaan, pengawasan dan evaluasi.

Teknik pengumpulan data menggunakan data kualitatif, dimana data kualitatif menurut Moleong (2009) Penggunaan jenis data ini berdasarkan bahwa data yang ada tidak 
berbentuk angka-angka atau nilai-nilai, untuk mendapatkan data yang relevan diperlukan teknik pengumpulan data yang tepat, dalam penelitian ini digambarakan teknik pengumpulan data yaitu observasi, wawancara, dokumentasi, dan triangulasi. Tempat penelitiannya di MTs Darul Ulum yang berloksi di desa cikembar dan MTs Darul Ulum berada di desa cimanggu, kedua MTs tersebut berada di Kecamatan Cikembar Kabupaten Sukabumi Provinsi Jawa Barat, sedangkan subjek penelitiannya adalah sumber data dari penelitian ini adalah semua yang bisa memberikan infor-masi dan data yang terdiri dari Guru dan Peserta Didik.

\section{HASIL DAN PEMBAHASAN}

\section{A. Hasil Penelitian}

1. Deskripsi Hasil Penelitian di MTs Darul Ulum Cikembar dan MTs Al Imam Cikembar

Perencanaan adalah kegiatan pertama yang seharusnya dilakaukan dalam manajemen oleh sebuah institusi, dari hasil penelitian yang dilakukan disekolah Darul Ulum dan Mts Al Imam Cikembar, sudah adanya visi, misi, serta tujuan madrasah, Mts Darul ulum dan Mts Al Imam Cikembar memiliki tujuan Mengkondisikan siswa untuk memiliki pe-mahaman kemampuan individu dan kecakapan teknis dasar yang dipersiapkan untuk melanjutkan pendidikan kejenjang yang lebih tinggi atau memiliki kecakapan yang memadai guna bersaing didunia lapangan kerja tetapi penyiapan Bahasa khususnya Bahasa Inggris kurang maksimal, terbukti kurang adanya penerapan model model pembelajaran ketika pembelajaran Bahasa Inggris, sehingga peserta didik kurang tertarik terhadap pembelajaran Bahasa Inggris, mereka mudah jenuh dan kurang bersemangat, dalam melaksanakan pembelajaran Bahasa Inggris, guru Bahasa Inggris memiliki perencanaan yang baik, hal ini terlihat adanya prosedur pembelajaran yang akan dilaksanakan dan beberapa tugas yang sering diterima oleh siswa, guru Bahasa Inggris selalu hadir dan tepat waktu sesuai jadwal yang ditentukan. Di madrasah ini menggunakan kurikulum Dua Ribu Tiga belas, Dokumen kurikulum Dua Ribu Tiga belas sudah sepenuhnya dibuat dan disusun secara bersama-sama oleh komponen madrasah yang terdiri dari semua unsur madrasah yaitu Kepala
Madrasah, para wakil kepala madrasah, guru dan tata usaha dengan melibatkan komite sekolah dibawah binaan pengawas madrasah, di lingkungan madrasah yang diteliti ini sudah melaksanakan pendampingan kurikulum 2013 melalui kegiatan IN-House Training (IHT) sebelum tahun ajaran baru dimulai. Sudah tersedia buku kerja guru 1 sampai 4, buku kerja guru 1 meliputi; analisis SKL, KI, KD, Silabus, RPP, KKM, buku kerja guru 2 meliputi; Kode Etik Guru, Ikrar Guru, Tata Tertib Guru, Pembiasaan Guru, Kalender Pendidikan, Analisis Alokasi Waktu, Program Tahunan, Program Semester, Jurnal Agenda Guru. Buku kerja guru 3; Daftar Hadir Siswa, Daftar Nilai Siswa, Penilaian Sikap Spiritual dan Sosial, Analisis Hasil Penilaian, Program Remidial dan Pengayaan, Daftar buku Pegangan Guru dan Siswa, Jadwal Mengajar Guru, Daya Serap Siswa, Kumpulan Kisi-kisi Soal, Kumpulan Soal, Analisis Butir Soal dan Perbaikan Soal. Berdasarkan hasil wawancara dengan peserta didik, diperoleh informasi bahwa dalam melaksanakan pembelajaran Bahasa Inggris, guru Bahasa Inggris memiliki perencanaan yang baik, hal ini terlihat dengan adanya prosedur pembelajaran yang akan dilaksanakan dan beberapa tugas yang sering diterima oleh siswa. Kemudian merekapun menuturkan guru bahasa Inggris sering melakukan berbagai model pembelajaran yang menarik sehingga mereka tidak bosan, mereka juga menuturkan bahwa guru bahasa Inggris dalam melaksanakan tugasnya selalu hadir dan tepat waktu sesuai jadwal yang ditentukan.

Dalam pelaksanaan penelitian pembelajaran bahasa Inggris melalui Contextual Teaching and Learning (CTL) dilaksanakan dengan teknik observasi. Pada pelaksanaan observasi diadakan pengamatan langsung terhadap aktivitas yang dilakukan oleh guru dan peserta didik selama proses pembelajaran berlangsung. Adapun kegiatan yang diamati selama proses pembelajaran bahasa Inggris melalui Contextual Teaching and Learning (CTL) adalah sebagai berikut:

a) Kegiatan Pendahuluan (apersepsi)

Pada kegiatan pendahuluan yang dilakukan oleh guru Bahasa Inggris ketika memasuki kelas meng-ucapakan salam pembuka (greeting) dan peserta 
didik meresponnya, kemudian berdoa dan dilanjutkan dengan mengecek kehadiran siswa, kegiatan selanjutnya mengulas dan menghubungkan materi yang telah diajarkan dengan materi yang akan diajarkan. Berdasarkan hasil wawancara dengan peserta didik diperoleh informasi bahwa siswa setuju dalam kegiatan pendahuluan, guru memotivasi dengan cara memberikan salam kepada peserta didik menggunakan Bahasa Inggris, bertegur sapa, mengatur keadaan kelas, dan menciptakan suasana belajar yang menyenangkan.

b) Kegiatan Pembelajaran

Pada kegiatan pembelajaran di-kelas VII di MTs Darul Ulum dan MTS Al Imam Cikembar meliputi:

1) Kegiatan Pendahuluan

Di dalam kegiatan pendahuluan ini guru melaksanakan kegiatan dengan bertanya jawab tentang:

a. Menanyakan tentang keadan siswa baik secara fisik maupun psikologis.

b. Apersepsi dengan mengkaitkan materi pembelajarn yang sebelumnya dengan materi yang akan dipelajari sekarang.

c. Penyampaian tujuan pembelajaran yang akan dicapai

d. Penyampaian cakupan materi dan uraian kegiatan.

2) Kegiatan Inti

a. Mengamati (Observing)

Peserta didik mengamati teks tentang teks prosedur yang ada dibuku penunjang siswa, kemudian siswa menjawab apa saja struktur teks prosedur dan tujuan dari teks prosedur tersebut; Peserta didik menjawab struktur teks prosedur.

b. Mempertanyakan (Questioning) Peserta didik mengajukan beberapa pertanyaan ke guru tentang kosa kata tersebut dan Peserta didik me-nanyakan tujuan dari teks prosedur.

c. Mengeksplorasi (Explorating) Peserta didik membagi kelompok dalam setiap kelompok terdiri 5 siswa dan mendapat teks prosedur yang susunannya acak, masing masing kelompok mendapat satu teks prosedur yang masing-masing berbeda; Pe-serta didik menyusun teks prosedur berdasarkan struk-tur teks yang benar; Peserta didik berdikusi menyusun teks prosedur yang benar; dan peserta didik menempelkan hasil tugas kelompoknya kepapan tulis.

d. Mengasosiasi (Associating)

Dalam kerja kelompok peserta didik dapat bekerja sama menyusun teks prosedur yang benar; dan guru berdiskusi dengan peserta didik mengenai susunan teks prosedur dari masing masing kelompok.

e. Mengkomunikasikan

(Networking)

Peserta didik mengkomunikasikan pemahaman dan kemampuannya dengan meminta mereka melakukan role play percakapn singkat tentang teks prosedur dan peserta didik membuat laporan evaluasi diri secara kelompok tentang teks prosedur.

3) Kegiatan Penutup

Memberikan umpan balik terhadap proses dan hasil pembelajaran, melakukan kegiatan tindak lanjut dalam bentuk pemberian tugas individual, serta menginformasikan rencana kegiatan pembelajaran untuk pertemuan yang akan datang.

Penilaian hasil pembelajaran menggunakan model pembelajaran Contextual Teaching and Learning (CTL) menganut prinsip penila-ian autentik yaitu penilaian yang sebenarnya yang mencakup penialian proses pembelajaran termasuk aktivitas siswa, per-kembangan karakter, dan pemahaman terhadap keterampilan yaitu kemampuan mendengarakan (listening), berbicara (speaking), membaca (reading), menulis (wraiting). Penilaian proses dalam pembelajaran Bahasa Inggris melalui Contextual Teaching and Learning (CTL) disekolah tersebut adalah dengan pengamatan (observasi) dan refleksi. Pengamatan ini dilakukan oleh guru bahasa Inggris ketika peserta didik sedang mengikuti pembelajaran, mengajukan pertanyaan/ permasalahan, merespon atau menjawab 
petanyaan, berdiskusi, dan mengerjakan tugas-tugas pembelajaran lainnya, baik di kelas maupun di luar kelas, dengan prinsip Contextual Teaching and Learning (CTL) yaitu konstruktivisme, menemukan, bertanya, masyarakat belajar, permodelan, refleksi, penilaian yang sebenarnya. Dari hasil wawancara dengan guru bahasa Inggris, diperoleh informasi bahwa selain menilai kemampuan penge-tahuan (kognitif), guru juga menilai kepribadian siswa selama proses pembelajaran seperti rasa tanggung jawab, percaya diri, saling menghargai, bersikap santun, kompetitif, dan jujur. Dari guru bahasa Inggris MTs Darul Ulum dan MTs Al Imam Cikembar dengan penerapan model pem-belajaran Contextual Teaching and Learning (CTL), guru menerapkan penilaian baik tes lisan maupun tulisan. Jenis-jenis tes yang dapat digunakan oleh guru misalnya tes tanya jawab (questionresponse test), tes tertulis (written test), penugasan, penilaian, kinerja/ demonstrasi, dan penilaian portofolio. Pengawasan dalam proses manajemen pembelajaran bahasa Inggris melalui Contextual Teaching and Learning (CTL) untuk meningkatkan prestasi belajar siswa dilakukan di MTs. Darul Ulum dan MTs Al Imam Cikembar, dilakukan oleh kepala sekolah adalah pembinaan berupa bimbingan atau tuntutan kearah perbaikan situasi pendidikan pada umumnya dan peningkatan mutu belajar dan mengajar pada khususnya. Tata cara pengawasan yang dilakukan oleh kepala sekolah terhadap guru dapat melalui diskusi kelompok, kunjungan kelas, pem-bicaraan individual dan simulasi pembelajaran. Adapun beberapa aspek yang akan di supervisi biasanya yang dilakukan di sekolah ini pada umumnya hampir sama yaitu aspek kepribadian guru, aspek kegiatan belajar mengajar kepala sekolah memeriksa administrasi mengajar guru, dan penguasaan akademik.

Faktor pendukung dalam manajemen pembelajaran bahasa Inggris melalui Contextual Teaching and Learning (CTL) untuk meningkatkan prestasi belajar siswa yaitu Motivasi belajar peserta didik, setiap peserta didik memiliki karakter dan kemampuan yang berbeda-beda dalam merespon pembelajaran. Dalam hal ini peserta didik dalam belajar bahasa Inggris sangat termotivasi sehingga jika sedang belajar bahasa yang Inggris membuat peserta didik kelas memiliki terasa hidup, cara belajar yang berbeda-beda motivasi penuh dari kepala sekolah untuk melaksanakan: adanya motivasi penuh dari kepala sekolah untuk mengembangkan modelmodel pembelajaran dan adanya kerjasama dengan guru bidang studi antara guru bidang studi sangat kooperativ sehingga hubungan antara guru yang satu dengan guru yang lain terjalin dengan baik.

Faktor penghambat dalam manajemen pembelajaran bahasa Inggris melalui Contextual Teaching and Learning (CTL) untuk meningkatkan prestasi belajar siswa yaitu:

a) Keterbatasan sarana dan prasarana, sarana dan prasarana yang masih kurang memadai dalam penyajian model pem-belajaran Contextual Teaching and Learning (CTL) berdampak pada kegiatan pembelajaran yang cenderung kurang berhasil. Dari hasil wawancara dikedua madrasah tersebut belum tersedia laboratorium bahasa Inggris, dari segi sarana masih kurang memadai seperti belum terpasangnya infokus disemua kelas, serta keterbatasan sarana audio visual yang kurang memadai.

b) Guru masih belum bisa konsisten dalam mengimplementasikan model pembelajaran Contextual Teaching and Learning (CTL), konsistensi guru dalam mengimplementasikan model pembelajaran Contextual Teaching and Learning (CTL) masih ditemukan di sekolah ini, begitupun yang terjadi di MTs Darul Ulum dan MTs Al Imam guru bahasa Inggris belum terlalu sering menggunakan model pembelajaran melalui Contextual Teaching and Learning (CTL) yang disesuaikan dengan materi pembelajaran.

c) Keterbatasan buku sumber pendukung, dari hasil wawancara dengan guru-guru Bahasa Inggris disekolah yang diteliti diperoleh informasi bahwa buku-buku sumber yang digunakan disekolah belum banyak mendukung model pembelajaran melalui Contextual Teaching and Learning (CTL) baik materi, kegiatan pembelajaran-nya maupun evaluasinya sehingga guru harus menggali berbagai sumber materi lain untuk memperkaya kegiatan baik 
melalui internet, maupun tayangan video.

\section{B. Pembahasan}

Deskripsi hasil Penelitian di MTs Darul Ulum Cikembar dan MTs Al Imam Cikembar

Dari hasil pengamatan yang peneliti peroleh guru Bahasa Inggris di kedua Madrasah ini melaksanakan kegiatan inti dengan berpedoman kepada RPP yang telah mereka susun. Kegiatan inti ini dilaksanakan selama 60 menit, sedangkan dalam kegiatan akhir dalam pembelajaran guru bahasa Inggris adalah dengan refleksi, kegiatan ini dilaksanakan untuk merenungkan kembali berbagai materi yang baru saja dipelajari, serta menegaskan munculnya pengetahuan dan perubahan karakter pada peserta didik. Pembelajaran melalui Contextual Teaching and Learning (CTL) kompetensi pengetahuan ini menjadi lebih bermakna karena siswa dapat memperluas pengetahuannya sedikit demi sedikit dan guru membantu siswa membuat hubungan antara pengetahuan yang telah dimiliki sebelumnya dengan pengetahuan yang baru, sehingga mereka mendapatkan pengetahuan yang berguna bagi dirinya untuk diimplementasikan dilingkungan kehidupannya. Hal ini pula yang terjadi si sekolah yang diteliti, guru melaksanakan melaksanakan kegiatan refleksi dengan mengecek kemampuan yang muncul pada diri siswa serta serta harapan untuk mengimplementasikannya ketika mereka berada diluar kelas, pada kegiatan refleksi, guru mendorong siswa untuk selalu bersikap positif pada dalam kehidupan, menanamkan semangat kebersamaan. Kegiatan akhir ini pun pada pelaksanannya guru Bahasa Inggris mengakhiri dengan penyimpulan materi yang telah dipelajari, penyimpulan materi yang dipelajari, kesimpulan materi yang disajikan, setelah itu guru memberikan penilaian dari masing-masing hasil belajar peserta didik baik secara kelompok maupun individu.

Hasil penilaian autentik ini diharapkan peserta didik bukan hanya menguasai materi secara teoritis (aspek kognitif) namun yang paling penting adalah bagaimana siswa dapat mengimplementasikan pengetahuan tersebut dalam kehidupan sehari hari (aspek psikomotor) sehingga terjadi perubahan tingkah laku ke arah yang lebih baik (aspek afektif). Terbukti dari hasil observasi di sekolah yang diteliti dapat dilihat bahwa kemampuan prestasi belajar siswa peserta didik menjadi lebih meningkat, siswa bukan hanya mampu merespon berbagai pertanyaan dalam bahasa Inggris dengan cukup lancar tapi juga mereka secara mandiri maupun kelompok menunjukkan berbagai kemampuan yang dimiliki melalui tulisan dan mampu meyampaikannya dengan benar. Hal ini membuktikan bahwa pembelajaran bahasa Inggris di sekolah yang diteliti dengan menggunakan model pembelajaran Contextual Teaching and Learning Model (CTL) meningkatkan prestasi belajar siswa. Munculnya empat kompetensi yaitu listening, mampu memotivasi dan reading sementara karakter-karakter mulia siswa speaking, writing, juga menunjukkan hampir seluruh siswa mampu mencapai KKM yan telah ditetapkan.

Dalam hal ini kepala sekolah yang diteliti di kedua sekolah ini telah melakukan pengawasan langsung terhadap guru dengan berbagai teknik teknik yang tepat sehingga membuat kinerja guru semakin disiplin, sedangkan pengawasan selama proses pembelajaran di kelas berlangsung dilakukan oleh guru bahasa Inggris tujuannya untuk mengetahui kelancaran pelaksanaan pembelajaran, mengetahui hambatan-hambatan yang terjadi dan mencari solusi jika terdapat masalah-masalah yang dihadapi, hasil pengawasan biasanya didiskusikan dengan pihak sekolah atau bahkan orang tua siswa. Pengawasan dilakukan untuk menjaga kelancaran proses belajar melalui Contextual Teaching and Learning (CTL) pembelajaran .yang dipimpin guru, atau saat anak sedang melakukan kegiatan belajar baik individual maupun kelompok. Pengawasan guru sangat dituntut agar tidak terjadi hal-hal yang tidak diinginkan, pada saat melakukan pengawasan ini, guru sekaligus melakukan penilaian sikap (afektif), pengetahuan (kognitif) keterampilan (psikomotor).

Faktor penghambat dalam manajemen pembelajaran bahasa Inggris melalui Contextual Teaching and Learning (CTL) adalah keterbatasan sarana dan prasarana dalam sarana dan prasarana yang masih kurang memadai dalam penyajian model pembelajaran Contextual Teaching and Learning (CTL) merupakan masalah besar, karena pembelajaran yang kurang didukung oleh sarana dan prasarana ada kecenderungan kurang berhasil. Dari hasil 
wawancara dikedua sekolah pada umumnya yang jadi kendala. Kurangnya ketersediaan sarana pendukung pembelajaran bahasa Inggris, yaitu belum tersedianya laboratorium bahasa Inggris, belum terpasangnya infokus disemua kelas, pembelajaran via internet yang belum memadai serta keterbatasan setiap kelas sarana audio visual, guru masih belum bisa konsisten dalam mengimplementasikan model pembelajaran Contextual Teaching and Learning (CTL). Konsistensi guru dalam mengimplementasikan model pembelajaran Contextual Teaching and Learning (CTL) masih ditemukan di kedua sekolah. Keterbatasan buku sumber pendukung dari hasil wawancara dengan guru-guru bahasa Inggris di sekolah yang diteliti diperoleh informasi bahwa buku-buku sumber yang digunakan di sekolah belum banyak mendukung model pembelajaran Contextual Teaching and Learning (CTL) sehingga guru harus menggali berbagai sumbermateri lain untuk memperkaya kegiatan baik melalui internet, maupun tayangan video.

\section{SIMPULAN DAN SARAN}

\section{A. Simpulan}

Proses pembelajaran bahasa Inggris menggunakan model pembelajaran Contextual Teaching and Learning (CTL) untuk meningkatkan prestasi belajar siswa diantaranya:

1. Perencanaan dilakukan sesudah program tahun ajaran baru berjalan, atas dasar musyawarah antara pihak kepala sekolah dan guru kegiatan untuk satu tahun direncanakan secara bersama-sama.

2. Pelaksanaan Pembelajaran melalui model pembelajaran melalui Contextual Teaching and Learning (CTL). Dalam pelaksanaan pembelajaran melalui model pembelajaran Contextual Teaching and Learning (CTL), kedua MTs mengorganisir kegiatan dengan baik. Pengorganisasian yang baik dan terencana dapat meminimalisir hambatanhambatan yang mungkin dihadapi pada saat pelaksanaan pembelajaran.

3. Pengawasan pelaksanaan pembelajaran di kedua MTs dilakukan secara periodik dan terprogram. Pengawasan yang dilakukan bertujuan untuk mengetahui kelancaran pembelajaran yang dilaksanakan, mengetahui hambatan-hambatan yang dihadapi selama pembelajaran dan menjaga situasi belajar agar tetap kondusif, sehingga tujuan pembelajaran dapat dicapai secara optimal.

4. Tahap penilaian atau evaluasi, pada prinsipnya kedua MTs memiliki kesamaan persepsi bahwa penilaian merupakan hal penting untuk mengetahui perkembangan kemampuan anak dalam berbagai bidang pengembangan, guru harus mengetahui jenis penilaian apa yang tepat untuk mencapai indikator tertentu.

5. Faktor pendukung dan penghambat merupakan hal yang selalu terjadi dalam proses pembelajaran, kedua MTs memiliki beragam faktor pendukung yang merupakan suatu kekuatan untuk mempertahankan kualifikasi baik yang selama ini telah dicapai. Usaha berbagai pihak baik dari Kepala Sekolah, guru-guru, staf Tata Usaha, orang tua siswa dan masyarakat di sekitar sekolah terlihat sudah maksimal, walaupun masih dapat diusahakan untuk lebih optimal.

\section{B. Saran}

Berdasarkan temuan di lapangan dan hasil penelitian yang telah disimpulkan maka penulis memberikan rekomendasi kepada berbagai pihak sebagai berikut:

1. Untuk Guru Bahasa Inggris

a) Hendaknya guru dalam pembelajaran tidak terbatas pada penyampaian informasi kepada peserta didik.

b) Dalam kegiatan pelaksanaan pembelajaran, guru sebaiknya memperhatikan tingkat kemampuan peserta didik dalam melaksanakan pembelajaran, salah satunya dengan memperbanyak belajar kolaborasi melalui kerja kelompok sehingga siswa dapat bertukar pengetahuan.

c) Guru hendaknya dapat mendalami tentang teknik-teknik evaluasi yang tepat.

d) Guru-guru harus memperhatikan perilaku peserta didik yang negatif, dan melarang perilaku-perilaku tersebut agar tidak terulang lagi.

e) Guru bisa memberikan pujian kepada mereka karena tidak melakukan perilaku negatif tersebut.

2. Untuk Kepala Sekolah

a) Kepala Sekolah dapat berpikir dan berbuat lebih kreatif untuk mencari gagasan baru dalam menjalankan tugasnya. 
b) Kooperasstif onerupakan sifat dan sikap yang diharapkan dalam kelancaran pengelolaan pembelajaran.

c) Kepala sekolah diharapkan selalu mendorong para guru dalam meningkatkan kualitas pembelajaran bahasa Inggris dengan menerapan model pembelajaran Contextual Teaching and Learning (CTL).

d) Keteladanan merupakan hal yang harus dilakukan oleh kepala sekolah dan diharapkan menjadi suatu kontrol bagi diri kepala sekolah agar dapat diikuti oleh stafnya.

3. Untuk Peneliti Selanjutya

Setelah penulis mengadakan penelitian ini, penulis ingin memberikan rekomendasi bagi peneliti selanjutnya agar dapat mengoptimalkan berbagai macam model pembelajaran serta mengenai peningkatan kompetensi guru, karena cukup menjadi kendala dalam proses pembelajaran di Madrasah Tsanawiyah.

\section{DAFTAR RUJUKAN}

Asmedy, A. (2021). Perbandingan Hasil Belajar Matematika Siswa yang diajar dengan Model Pembelajaran Possing Problem Berkelompok dan Metode Ceramah. Jurnal Inovasi, Evaluasi Dan Pengembangan Pembelajaran (JIEPP), 1(2), 69-75. https://doi.org/10.54371/jiepp.v1i2.107

Depdikbud, 2014. Strategi Belajar dan Pembelajaran Implementasi Kurikulum 2013. Jakarta: Depdikbud

Johnson, B.E. 2010. Contextual Teaching \& Learning. Bandung: Kaifa
Moleong, L. J. 2009. Metodologienelitian Kualitatif. Bandung: PT. Remaja Karya.

Mulyasa, E. 2015. Menjadi Guru Profesional Menciptakan Pembelajaran Kreatif dan Menyenangkan. Bandung: PT Remaja Rosdakarya

Nurhasanah, E. (2021). Pengaruh Media Pembelajaran Berbasis Flashcard Huruf Hijaiyah terhadap Hasil Belajar Iqro pada Santri The Gold Generation. Jurnal Inovasi, Evaluasi Dan Pengembangan Pembelajaran (JIEPP), 1(2), 60-68. https://doi.org/10.54371/jiepp.v1i2.106

Pembelajaran. Bandung: Humaniora. Hanafiah, N. dan Suhana, C. 2009. Konsep Strategi Pembelajaran. Bandung: Refika Aditama

Rinjani, C., Wahdini, F. I., Mulia, E., Zakir, S., \& Amelia, S. (2021). Kajian Konseptual Model Pembelajaran Word Square untuk Meningkatkan Hasil Belajar Siswa. Jurnal Inovasi, Evaluasi Dan Pengembangan Pembelajaran (JIEPP), 1(2), 52-59. https://doi.org/10.54371/jiepp.v1i2.102

Sari, W., Murtono, M., \& Ismaya, E. 2021. PERAN GURU DALAM MENINGKATKAN MOTIVASI DAN MINAT BELAJAR SISWA KELAS V SDN TAMBAHMULYO 1. Jurnal Inovasi Penelitian,1(11), 2255-2262. https://doi.org/10.47492/jip.v1i11.472

Sugiyono. (2014). Metode Penelitian Pendidikan Pendekatan Kuantitatif, Kualitatif, dan $R \& D$. Bandung: Alfabeta. 